\title{
Evaluation of yield and pest and disease resistance of cocoa clones in Kolaka District, Southeast Sulawesi, Indonesia
}

\author{
RUBIYO $^{1, \bullet}$, Y.A. DEWI ${ }^{1, \bullet \bullet}$, IMRAN $^{2}$, AGUS SALIM ${ }^{2}$, BAHARUDIN $^{2}$, CHANDRA INDRAWANTO $^{1}$, \\ M.T. RATULE ${ }^{3}$ \\ ${ }^{1}$ Indonesian Center for Agricultural Technology Assessment and Development. Jl. Tentara Pelajar No. 10, Bogor 16114, West Java, Indonesia. \\ Tel.: +62-251-8351277, `email: rubiyo63@gmail.com, v•yovi_anggita@yahoo.com \\ ${ }^{2}$ Assessment Institute for Agricultural Technology of Southeast Sulawesi. Jl. Moh. Yamin, Puwatu, Kendari 931114, Southeast Sulawesi, Indonesia \\ ${ }^{3}$ Indonesian Center for Horticulture Research and Development. Jl. Tentara Pelajar No. 3C, Cimanggu, Bogor 16111, West Java, Indonesia
}

Manuscript received: 24 August 2020. Revision accepted: 15 November 2020.

\begin{abstract}
Rubiyo, Dewi YA, Imran, Salim A, Baharudin, Indrawanto C, Ratule MT. 2020. Evaluation of yield and pest and disease resistance of cocoa clones in Kolaka District, Southeast Sulawesi, Indonesia. Biodiversitas 21: 5698-5607. Cocoa is one of the main plantation commodities in Indonesia. It is an important source of foreign exchange and employment. Currently, Indonesian cocoa production and productivity, including in Southeast Sulawesi, are declining due to pests and diseases. In addition, there is a lack of highquality and high-yielding clones. This study aimed to evaluate the quality of cocoa clones and resistance to cocoa pod borer (CPB) and cocoa pod rot (CPR) disease caused by the fungus Phytophthora palmivora. The study tested 12 cocoa clones, which included four highyielding clones. The research location was in Lambandia Subdistrict, Kolaka District, Southeast Sulawesi Province, Indonesia. Clonal planting material was propagated by grafting in 2010. The study used a randomized block design and the treatments consisted of 20 plants of each cocoa clone with three replications. The clones were evaluated from 2018 to 2019. The observed variables included resistance to CPB and CPR. The results of the study based on the quality component showed that the clones MT, M04, and M01 had the highest average weight per one dry bean of $1.55 \mathrm{~g}, 1.64 \mathrm{~g}$, and $1.24 \mathrm{~g}$, respectively. Beans produced by clones MT, M01, and M04 had an average fat content of $53.36 \%, 52.72 \%$, and $50.76 \%$, respectively. Observations of the average number of pods with CPR showed that the lowest rate of attack (about 6\%) was in BAL 209 and PT. Ladongi clones, with attack intensities of 20\% and 18\%, respectively; therefore, these clones were classified as resistant to CPR. Evaluation of the level of resistance to attack by CPB pests found two resistant clones, PT. Ladongi and Sulawesi 2, with light levels of attack on beans.
\end{abstract}

Keywords: Clones, cocoa, quality, yield, pest and disease resistance

Abbreviations: CPB: cocoa pod borer, CPR: cocoa pod rot, RBD: randomized block design

\section{INTRODUCTION}

Indonesia is in the top three cocoa bean exporting countries in the world after Cote D'Ivoire and Ghana; it contributes about $14.7 \%$ to the world cocoa production (Campos Vega et al. 2018). Cocoa farming in Indonesia plays a crucial role as a source of foreign exchange and employment opportunities as well as income for farmers; however, the cocoa acreage is declining. The total area under cocoa cultivation in Indonesia was 1.72 million hectares in 2016, which decreased to 1.658 million hectares in 2017, although it slightly increased in 2018 to 1.678 million hectares (DGEC 2019). Indonesian cocoa production recorded in world trade has significantly declined from 440 thousand tons in 2011 to 270 thousand tons in 2017 (ICCO 2019).

The development of cocoa farming in Indonesia faces several problems. For instance, the low quality of cocoa beans is a major problem for processors. In addition, dry cocoa beans are not generally fermented, although this process is necessary to develop flavor (Afoakwa et al. 2014; Kongor et al. 2016) and color (Afoakwa et al. 2014; Hastuti et al. 2019), as well as to add value to sundried cocoa beans (Apriyanto 2016; Apriyanto et al. 2016). The total polyphenolic content of fermented cocoa from Indonesia is low ( $\mathrm{Gu}$ et al. 2013). Cocoa productivity varies greatly between regions in Indonesia and tends to be lower than its potential productivity (Witjaksono and Asmin 2016; Rubiyo and Dewi 2018); Indonesia's productivity has remained the lowest among the prominent cocoa-producing countries (Glorya and Nugraha 2019). Losses due to infection with black pod disease in cocoa plantations are between 20-25\% per year (Adeniyi 2019). Cocoa pod rot (CPR) caused by Phytophthora palmivora is found in Africa, America, and Asia, including in Indonesia, Malaysia, and Papua New Guinea (Acebo-Guerrero et al. 2012; Ali et al. 2017; Akrofi et al. 2017; Ling et al. 2017; Ndoungue et al. 2018; Chang et al. 2020).

Poor harvests are also experienced in Southeast Sulawesi where cocoa plantations tend to produce lowquality cocoa beans and their productivity is less than 650 $\mathrm{kg} \mathrm{ha}^{-1}$ due to an inadequate cultivation system and attack by the cocoa pod borer (CPB) Conopomorpha cramerella Snellen (Rubiyo and Siswanto 2012; Ruf and Yaddang 2014), as well as $P$. palmivora causing CPR (Dewi et al. 2020; Chang et al. 2020). These pests can reduce 
production by up to $30 \%$ and cause damage to about $10 \%$ of the crop (Acebo-Guerrero et al. 2012). Cocoa bean losses in Ladongi, Southeast Sulawesi can reach $50 \%$ due to the main pest and diseases (McMahon et al. 2010a) so that the average cocoa production in Southeast Sulawesi is now $690 \mathrm{~kg} / \mathrm{ha} /$ year, a decrease of $37 \%$ from the 1,100 $\mathrm{kg} / \mathrm{ha} /$ year in previous years.

To resolve the problem of low productivity of cocoa requires technological improvements, such as high-yielding clones with high productivity (Rubiyo and Siswanto 2012; Witjaksono and Asmin 2016), pest and disease management (Daymond et al. 2017), fertilization (Abdulai et al 2020), and pruning management (Tothmihaly and Verina 2017; Effendy et al 2019). Planting resistant clones is a promising strategy (McMahon et al. 2010b; AduAcheampong et al. (2015) although it is difficult to find cocoa clones fully resistant to CPB (Niogret 2020). The selection process requires adequate knowledge of environmental and genetic factors and a reliable process for screening for resistance, for example, the leaf disc and detached pod tests (Efombagn 2011). Cultivation of resistant clones is the most beneficial way of controlling diseases because it is environmentally friendly (Ling et al. 2017). Availability of information on the yield of pest-and disease-resistant cocoa is important, so that farmers can easily select and plant clones with resistance to pests and diseases while maintaining optimal productivity.

This study aims to obtain basic information for cocoa growers on resistance of cocoa clones to CPR disease due to P. palmivora infection and CPB in Southeast Sulawesi. This study also identified high-yielding and high-quality clones, resistant to the main pests and diseases, that can be adopted by cocoa farmers, in particular in the Southeast Sulawesi region.

\section{MATERIALS AND METHODS}

\section{Cocoa quality evaluation}

This study selected genetic material by exploring the results of a previous study of individual parent trees based on 79 cocoa clones conducted from 1998 to 2010. Eight clones were selected based on yield parameters. The eight selected clones and four national high-yielding clones, used as a comparison in 2010-2014, were tested in Lambandia Village, Lambandia Subdistrict, Kolaka District, Southeast Sulawesi Province, Indonesia. The total study area was one hectare.

Evaluation of quality and resistance was carried out in 2018-2019; as a comparison, the four national highyielding clones, ICCRI 03, ICCRI 04, Sulawesi 1, and Sulawesi 2, were also tested, so that the total number of clones assessed was 12 . The study used a randomized block design with treatments consisting of the 12 cocoa clones (the four national high yielding clones and the eight cocoa clones selected for yield parameters) with three replications and each treatment consisting of 20 plants.

The planting material used in the study was a threeyear-old clonal cocoa plant from continuous propagation. The rootstock used cocoa beans from farmers' plants with
12 clones of entres, namely Sulawesi 1, Sulawesi 2, ICCRI 03, ICCRI 04, KKM 22, PT. Ladongi, M04, Amirudin, Lambandia 01, BAL 209, and MT. The equipment used included counters, plastic bags, gauges, and other supporting tools. The parameters measured included (1) number of beans/fruit, (2) wet weight per fruit, (3) weight of wet beans per fruit, (4) weight of dry beans per fruit, (5) level of shell or yield of peeled beans, (6) bean yield, (7) number of beans per 100 grams, (8) weight of 100 beans, (9) average weight per dry bean, and (10) cocoa butter content.

Water content was expressed as a percentage of weight per equal weight and calculated as:

$$
\frac{M_{1}-M_{2}}{M_{1}+M_{0}} \times 100 \%
$$

and waste content and foreign matter content were expressed by percentage weight per weight and calculated as:

$$
\frac{M_{2}-M_{1}}{M_{0}} \times 100
$$

Where; $\mathrm{M}_{0}$ : sample weight $(\mathrm{g}), \mathrm{M}_{1}$ : weight of empty glass/ empty cup (g), and $\mathrm{M}_{2}$ : weight of glass/cup and dirt ( $\mathrm{g}$ )

Broken bean content was expressed as percentage of weight per weight (equation 3):

$$
\frac{M_{2}-M_{1}}{M_{0}} \times 100 \%
$$

Where; $\mathrm{M}_{0}$ : sample weight $(\mathrm{g}), \mathrm{M}_{1}$ : weight of glass/ empty cup (g), and $\mathbf{M}_{2}$ : weight of glass/cup and broken beans $(\mathrm{g})$.

The experimental results were stated with the number of beans counted in $100 \mathrm{~g}$ of the test sample as follows: the number of beans (x) until 85 were grade AA; the number of beans (x) until 100 were grade $A$; the number of beans (x) until 110 were grade $\mathrm{B}$; the number of beans $(\mathrm{x})$ until 120 were grade $C$; and the number of beans $(x)>120$ were grade $\mathrm{S}$.

The broken bean content in each category was expressed as percentage of beans using the equation

$$
\frac{M_{1}}{M_{0}} \times 100 \%
$$

where $\mathrm{M}_{0}$ : the number of beans in test sample (300 cocoa beans) and $\mathrm{M}_{1}$ : each of broken bean.

Dry bean weight (g) was obtained using an analytical scale with equation 5 (Sulistyowati and Sulisyowaty 1993):

$$
\text { Pod Index }=\frac{100 \mathrm{~g}}{\text { Dry bean weight } \mathrm{x} \text { number of beans per fruit }}
$$

Yield (\%) was calculated using equation 6 (Sulistyowati and Santosa 1992):

$$
\text { Yield }=\frac{\text { dry bean weight of fruit-1(gr) }}{\text { avergare of fruit weight }\left(\mathrm{gr}^{2}\right)} \times 100 \%
$$


The physical and chemical qualities (e.g., fat content) of cocoa beans were analyzed at the end of the observations. The population of grafted productive plants was chosen from three-year-old plants that were fruiting. The population of plant samples consisted of 108 trees planted at a spacing of $3 \times 3 \mathrm{~m}$. Ten samples were taken from each of the 12 clones and replicated three times so that the observations were based on 360 samples.

\section{Evaluation of resistance to cocoa pod borer}

The second experiment evaluated the level of cocoa plant resistance based on pest attacks on the 12 clones. Observations of CPB attacks were made on 100 fruit samples per replicate for each treatment/clone. Observations of CPB attack on beans was carried out during the harvest cycle. All ripe fruit was split open and CPB damage was assessed. Each clone was replicated three times, so each treatment/clone required 300 cocoa pods for observations. The observed parameters of CPB attacks were as follows.

The proportion (\%) of sticky beans caused by CPB: Based on the percentage of sticky beans, plant responses were classified into light (sticky beans <20\%), moderate (20-50\% sticky beans), and heavy (>50\% sticky beans) (Azhar et al. 1995).

The percentage of $C P B$ pest attacks:

The attack percentage was calculated using equation 7 (Sulistyowati et al. 2005):

$$
\mathrm{P}=\frac{\mathrm{a}}{\mathrm{a}+\mathrm{b}} \quad x 100 \%
$$

Where; P: \% of fruit attacked, a: number of fruit attacked by $\mathrm{CPB} /$ tree, and $\mathrm{b}$ : number of fruit not attacked by $\mathrm{CPB} /$ tree.

Lim (1982) categorized CPB attack of cocoa plants as heavy (54\%), moderate (34\%), and light (12\%) attacks. The scores for the damage intensity categories were 1 if $\mathrm{X}$ $>54 \%, 3$ if $12 \%<\mathrm{X}<54 \%$, and 5 if $\mathrm{X}<12 \%$.

The number of entry holes and the number of exit holes of CPB larvae were observed on the sample trees. The sample size was $10 \%, 20 \%$ and $30 \%$ of the total tree population. Observations were made on the number of $\mathrm{CPB}$ entry/exit holes and the total number of fruits per tree. Cocoa pods with traces of entry or exit holes were assumed to be affected by CPB.

$$
\mathrm{P}=\frac{\mathrm{a}}{\mathrm{a}+\mathrm{b}} \quad \mathrm{x} 100 \%
$$

Where; P: \% CPB attacks, a: the number of fruit with entrance/exit holes/tree, and $b$ : the number of fruit/tree.

\section{Evaluation of resistance to cocoa pod rot disease}

The resistance to CPR disease of side-grafted cocoa was assessed from disease intensity. The total number of samples consisted of 12 clones replicated three times, and each treatment consisted of 20 clonal plants. The observations started six days after inoculation with the scoring of the severity of symptoms on the surface of tested cocoa fruits and disease intensity index (DII). Observations were made every day but ceased if there were cocoa pods or plants that died due to $P$. palmivora infection. Spot symptoms were detected with the disease symptom scoring parameter according to a modification of Fry's (1982) method shown in Table 1 . The disease intensity value was used to classify plants into five categories (Table 2).

From the score data, the disease index was determined using equation 9:

$$
D I=\frac{\sum_{i=1}^{n} n \cdot N}{z \cdot N} \times 100 \%
$$

Where; DI: disease intensity, N: the number of scored plants, V: score i, and Z: the highest score value.

\section{RESULTS AND DISCUSSION}

\section{Cocoa quality evaluation}

Weight of harvested fruit

The results showed that the fruits of clones K12 and K2 were significantly heavier than those of the other clones (Table 3). Based on the fruit growing on the cocoa tree, the heaviest fruit is on the trunk position. The level of fruit maturity is indicated by physiological changes consisting of changes in skin color, aroma, and hardness of cocoa pods. The important factors during the fruit ripening process are the changes in moisture content, weight, and size of the beans. Rojas et al. (2020) suggested that the weight of fruit, number of seeds, and fruit color and firmness could be used as harvest indicators while fruit size was not recommended as an indicator of ripeness. During physiological ripening, translocation of nutrients in the beans will stop. Based on the location of the growing pods on the tree, the largest cocoa pods were on the trunk and the smallest on secondary branches. This was possibly because the ability to access nutrients for pod development is greater on the trunk than on tree branches.

Table 1. Spot symptom score for Phytophthora palmivora infection, according to Fry (1982).

\begin{tabular}{lll}
\hline Score & Attacks & Symptoms \\
\hline 0 & Healthy & $0 \%$ infected \\
1 & Very light & $<5 \%$ infected leaves/fruits. \\
2 & Light & $\begin{array}{l}5-10 \% \text { infected leaves/fruits, chlorosis, } \\
\text { necrotic, no fallen leaves, lenticel swelling }\end{array}$ \\
3 & Moderate & $\begin{array}{l}10-25 \% \text { infected leaves/fruits, chlorosis, } \\
\text { necrotic, fallen leaves, lenticel swelling }\end{array}$ \\
4 & Rather & $\begin{array}{l}25-50 \% \text { infected leaves/fruits, chlorosis, } \\
\text { necrotic, fallen leaves, lenticel swelling }\end{array}$ \\
5 & heavy & $\begin{array}{l}50-75 \% \text { infected leaves/fruits, chlorosis, } \\
\text { Heavy }\end{array}$ \\
6 & Vecrotic, fallen leaves, lenticel swelling \\
& heavy & $\begin{array}{l}>75 \% \text { infected leaves/fruits, chlorosis, necrotic, } \\
\text { fallen leaves, lenticel swelling, dead beanlings }\end{array}$ \\
\hline
\end{tabular}

Table 2. Classification of cocoa plant resistance to Phytophthora palmivora

\begin{tabular}{lc}
\hline Category & Disease intensity $(\%)$ \\
\hline Resistant & $0-30$ \\
Rather resistant & $31-50$ \\
Moderate & $51-65$ \\
Rather susceptible & $66-80$ \\
Susceptible & $81-100$ \\
\hline
\end{tabular}


Table 3. The average weight of harvested fruit, shell content, yield, average number of beans per 100 gram and weight per 100 beans of cocoa clones in the study site

\begin{tabular}{|c|c|c|c|c|c|}
\hline \multirow[b]{2}{*}{ Clone } & \multicolumn{5}{|c|}{ Observed variables } \\
\hline & $\begin{array}{c}\text { Average weight of } \\
\text { harvested fruit (grams) }\end{array}$ & $\begin{array}{l}\text { Cocoa shell } \\
\text { content }(\%)\end{array}$ & $\begin{array}{l}\text { Yield } \\
(\%)\end{array}$ & $\begin{array}{c}\text { Average number of } \\
\text { beans } / 100 \text { grams }\end{array}$ & $\begin{array}{c}\text { Average weight/100 } \\
\text { beans (grams) }\end{array}$ \\
\hline K1 (Sulawesi 1) & $370.32 \mathrm{e}$ & $12 \mathrm{~b}$ & 17.37 & $99 \mathrm{f}$ & $110.29 \mathrm{c}$ \\
\hline K2 (M01) & $636.34 \mathrm{~b}$ & $12 \mathrm{~b}$ & 29.99 & $100 \mathrm{f}$ & $101.08 \mathrm{~d}$ \\
\hline K3 (ICCRI 03) & $303.31 \mathrm{~g}$ & $18 \mathrm{a}$ & 22.17 & $150 \mathrm{a}$ & $77.63 \mathrm{e}$ \\
\hline K4 (ICCRI 04) & $286.78 \mathrm{~g}$ & $18 \mathrm{a}$ & 22.74 & $141 \mathrm{~b}$ & $80.11 \mathrm{e}$ \\
\hline K5 (PT. Ladongi) & $331.02 \mathrm{f}$ & $6 \mathrm{c}$ & 18.55 & $106 \mathrm{e}$ & $95.61 \mathrm{~d}$ \\
\hline K6 (M04) & $573.40 \mathrm{c}$ & $10 \mathrm{~b}$ & 26.98 & $83 \mathrm{~g}$ & $123.65 \mathrm{~b}$ \\
\hline K7 (Amirudin) & $394.14 \mathrm{e}$ & $10 \mathrm{~b}$ & 21.92 & $130 \mathrm{c}$ & $81.97 \mathrm{e}$ \\
\hline K8 (Sulawesi 2) & $403.15 \mathrm{e}$ & $21 \mathrm{a}$ & 16.23 & $107 \mathrm{e}$ & $95.86 \mathrm{~d}$ \\
\hline K9 (Lambadia 01) & $398.20 \mathrm{e}$ & $12 \mathrm{~b}$ & 19.16 & $100 \mathrm{f}$ & $92.50 \mathrm{~d}$ \\
\hline K10 (BAL 209) & $333.83 \mathrm{f}$ & $6 c$ & 20.52 & $117 \mathrm{~d}$ & $86.56 \mathrm{e}$ \\
\hline K11 (KKM 22) & $466.90 \mathrm{~d}$ & $10 \mathrm{~b}$ & 22.10 & $114 \mathrm{~d}$ & $85.50 \mathrm{e}$ \\
\hline $\mathrm{K} 12$ (MT) & $861.43 \mathrm{a}$ & $12 \mathrm{~b}$ & 26.55 & $76 \mathrm{~h}$ & $144.16 \mathrm{a}$ \\
\hline Average & 446.57 & 12.25 & 22.02 & 110.25 & 97.91 \\
\hline Standard deviation & 167.75 & 4.63 & 4.12 & 21.86 & 19.70 \\
\hline
\end{tabular}

Note: The numbers followed by the same letter in each column are not significantly different according to the Scott-Knott test at the $5 \%$ significance level

\section{Shell content of dry cocoa beans}

The results of the assessment of dry cocoa shell content (Table 3) show that the M01 clone produced the highest yield of peeled nibs, while the Sulawesi 2 clone had the lowest yield. Variance analysis of the yield of peeled nibs showed that the clones could be classified into six groups based on the physical quality and nib content of the bean and the bean coat yield. The K2 clone had the highest shell content of $23.1 \%$ and $\mathrm{K} 8$ had the lowest. Shell content of unfermented beans ranges from $12.8 \%$ to $25.1 \%$ depending on the length of pod storage (Afoakwa et al. 2011). The chocolate food industry requires a bean coat that falls off easily but is strong enough to prevent breaking; therefore, beans need proper handling. During the fermentation process, the pulp carbohydrates are broken down (Lefeber et al. 2011). In this study, prior to drying cocoa beans at the research location, the beans were fermented. The fermentation technique and time are essential determinants of cocoa bean quality, especially flavor (Kongor et al. 2016; Sudibyo 2017). The longer the fermentation process, the more optimal the decomposition process will be, so that less pulp remains on the shell and the nib content decreases.

Apart from the drying process, fermentation is also considered a crucial step in cocoa bean production (Afoakwa et al. 2011a, b; Gu et al. 2013; Giacometti et al. 2015). One of the purposes of fermentation is to reduce the moisture content of cocoa beans and improve the quality of cocoa products; however, implementation at the farmer level is still low. Hence, training and advice are indispensable to enhance farmers' knowledge and capacity to improve cocoa quality. The provision of facilities and infrastructure also plays an important role, for instance, installation of cocoa bean fermentation units to produce beans with better value for making cocoa paste, cocoa butter, cocoa powder for chocolate drinks, chocolate ice cream, and other products (Juniaty et al. 2012).
The high shell content in cocoa is determined by the planting material and processing method (fermentation and washing). Processing without fermentation results in a large amount of pulp adhering to the bean coat due to the lack of decomposition of carbohydrates in the pulp. Cocoa shell is the remaining content of the ripe cocoa fruit after processing, which is generally $67-76 \%$ of the whole fruit (Oddoye et al. 2013). The cocoa beans consist of a nib protected by the shell. The cocoa shell content is calculated based on the ratio of shell weight to the total weight of cocoa beans (shell + nibs) at a moisture content of 7-7.5\% The typical standard for cocoa shell content is between 11$13 \%$, but the value of the hull grade generally depends on consumer demand. Cocoa beans with high skin content tend to be stronger or less brittle when stacked in a warehouse, so they can be stored for a longer time. If the shell content is too low, the cocoa beans will lose weight during storage. The general requirements for exported cocoa beans are the size of the beans, the degree of dryness, and the level of foreign matter contamination. Quelal-Vásconez et al. (2020) mentioned five quality attributes for cocoa beans, four for chocolate, and two for cocoa powders. Bean size is expressed as the number of beans per 100 grams of dry cocoa beans; it can be categorized into three levels (QuelalVásconez et al. 2020). However, in Indonesia, the quality classification based on beans size has 5 grades (INS 2002).

As shown in Table 3 , the average bean yield can be categorized into six groups from A to F. The results show that $\mathrm{K} 8$ and $\mathrm{K} 1$ had the highest bean yield. The yield of $\mathrm{K} 9$ beans was different from the other groups and K10. K7, $\mathrm{K} 11, \mathrm{~K} 3$, and $\mathrm{K} 4$ had similar bean yields, while the yield of $\mathrm{K} 12$ beans was the same as that of K6, whereas K2 had the lowest bean yield and was grouped separately from the other groups. 
Number of beans per 100 grams

The results for quality based on the average number of dry cocoa beans per 100 grams showed that the clone with the highest number of beans per 100 grams was K3 (ICCRI 03) with an average of 150 beans per 100 grams, followed by K4 and K7 which had 141 beans per grams and 130 beans per grams, respectively. On the other hand, K12 produced only 76 beans per 100 grams, the fewest among the clones studied (Table 3).

Based on the results of further tests, clones $\mathrm{K} 3, \mathrm{~K} 4$, and K7 were significantly different from the others in the average number of beans. K10 had a similar number of beans per 100 grams as K11, with the average number of beans per 100 grams being 117 and 114, respectively, while $\mathrm{K} 8$ and $\mathrm{K} 5$ also had similar numbers of beans per 100 grams, with 107 and 106 beans, respectively. K2, K9, and $\mathrm{K} 1$ also had a similar yield in the number of beans per 100 grams. K6 with an average of 83 beans per 100 grams was grouped separately from the other groups, as also was K12 with an average of 76 beans per 100 grams. As can be seen from Table 3, the average number of beans per 100 grams and the average weight of 100 fresh beans appear to be negatively correlated, with the smaller the number of beans per 100 grams and the heavier the weight per 100 beans.

The number of beans in $100 \mathrm{~g}$, moisture level, and the cut test are often used as quality indicators of cocoa from different regions of cultivation, which might produce cocoa of varying quality (Hashimoto 2017). The size of the cocoa bean is the physical characteristic determining the fat yield. The fat yield from larger cocoa beans is higher; therefore, bean size is highly important for yield. The fat yield also steadily decreases as pod storage time increases (Afoakwa et al. 2011b). Cocoa bean size was expressed as the number of beans (beans account) per 100 grams of sample taken randomly at a moisture content of $7-7.5 \%$, which is the standard set by the Indonesian National Standard Agency.

The average size of beans of export quality is between 1.0-1.2 grams or equivalent to 85-100 beans per 100 grams. In this study, based on the weight of 100 beans, the 12 clones could be separated into five groups. K12 (MT) had the highest weight for 100 beans compared to the other clones. Furthermore, the average weight of 100 beans was $123.65 \mathrm{~g}$ for $\mathrm{K} 6$ and $110.29 \mathrm{~g}$ for $\mathrm{K} 1$, while $\mathrm{K} 2$, K8, K5, and $\mathrm{K} 9$ had similar weights. In addition, K10, K11, K7, $\mathrm{K} 4$, and $\mathrm{K} 3$ had comparable weights. The regulation of quality standards for cocoa beans generally varies between countries, with country-specific standardization and quality control. Each exported cocoa bean must meet the applicable standards of the quality control system. Good quality cocoa beans will result in good quality products (Owosu 2010) considering that optimal results are obtained from fully fermented cocoa beans as the raw material. Teye et al. (2019) underlined the variability in the quality of cocoa beans from different countries due to the differences in the main processing techniques, particularly fermentation and drying.

\section{Wet bean weight and dry bean weight per fruit}

The Scott-Knott test results in Table 4 show that there are three distinct significantly different groups among the 12 clones. The wet bean weight of K5, K9, K11, and K2 were similar. Clones K3, K1, K8, K10, K4, and K7 were comparable, with the last two clones with the lowest wet weights. The results for average dry bean weight showed different trends since they could be used to categorize the 12 clones into four different groups. K12, K6, and K9 produced the highest dry weights while K11 and K5 produced the second highest. Furthermore, bean dry weight was comparable for $\mathrm{K} 1, \mathrm{~K} 7, \mathrm{~K} 8, \mathrm{~K} 3$, and $\mathrm{K} 10$, and $\mathrm{K} 2$ and $\mathrm{K} 4$ produced beans with the lowest dry weight. Dry bean weight makes a significant contribution to the yield and economic value of cocoa (Deepa et al. 2019). Both gross and net weight of Indonesian cocoa beans is higher than those of beans from Papua New Guinea and China where several aspects influenced bean weight (Gu et al. 2013).

The evaluation of the average dry weight of cocoa beans showed variation between clones. There was a carrying capacity between families of rootstocks on the vigor of stem growth, but this did not affect the quality of yield of stems on cocoa clones. They greatly affected the number of beans per fruit and the weight of the beans. The yield data were a reflection of the quality evaluation in the first harvest season. The clones used in this study are among those recommended by the Indonesian Ministry of Agriculture, and they are well adapted to the agro-climatic conditions in Southeast Sulawesi due to the side-grafting technology. The K12 clone had the highest quality of dry bean at $40.66 \%$ compared to the other clones so that it has the potential for producing a bean weight of $>1 \mathrm{~g}$. This percentage is in line with the Indonesian National Standard (INS) requirements for exports. According to Susilo et al. (2006), several recommended cocoa clones have the potential for improvement in cultivation under more optimal environmental conditions, for example in regions with a wet climate.

\section{Weight of one dry bean and fat content of cocoa}

The K6 (M04) clone had the highest average weight for one dry bean among all clones, followed by MT and PT. Ladongi, while Sulawesi 2 had the lowest average (Table 4). These results show that the cocoa clones generally produced a bean with a dry weight of above 1 gram. ICCRI 3 and the four national cocoa clones yielded beans with a dry weight of $<1 \mathrm{~g}$; this may be due to the possibility that the clones did not produce optimal fruit so that the beans were less pithy. ICCRI 3 and 4 clones are suitable for cultivation under the agro-ecosystem conditions in Southeast Sulawesi; therefore, it is necessary to carry out further observations in the next fertilization period. The Sulawesi 1 clone recommended for the Sulawesi region produced beans of the lowest weight $(0.52 \mathrm{~g})$.

The weight of cocoa beans from the Sulawesi 2 clone was less than that from previous studies in other locations. It is possible that nutrients and climatic conditions affected the quality of the beans produced. In general, the clones that produced the highest dry bean weight were MO4 (1.64 $\mathrm{g})$ and MT (1.55 g). Both clones were the result of local cocoa exploration. It is expected that these cocoa clones would provide consistency in yield and bean quality and resistance to major pests and diseases so that they have the potential to be released as new high-yielding clones. 
Table 4. The physical and chemical characteristics of cocoa bean produced by 12 clones in the study site

\begin{tabular}{|c|c|c|c|c|}
\hline Clones & $\begin{array}{c}\text { Wet bean weight/pod } \\
\text { (grams) }\end{array}$ & $\begin{array}{c}\text { Dry bean weight/pod } \\
\text { (grams) }\end{array}$ & $\begin{array}{c}\text { Weight of one dry } \\
\text { bean (grams) }\end{array}$ & Fat content $(\%)$ \\
\hline K1 (Sulawesi 1) & $111.72 \mathrm{c}$ & $31.91 \mathrm{a}$ & $1.33 \mathrm{a}$ & 50.92 \\
\hline K2 (M01) & $128.31 \mathrm{~b}$ & $25.73 \mathrm{~d}$ & $1.24 \mathrm{a}$ & 52.72 \\
\hline K3 (ICCRI 03) & $119.20 \mathrm{c}$ & $30.43 \mathrm{c}$ & $0.87 \mathrm{~b}$ & 50.70 \\
\hline K4 (ICCRI 04) & $92.41 \mathrm{c}$ & $22.04 \mathrm{~d}$ & $0.88 \mathrm{a}$ & 51.75 \\
\hline K5 (PT. Ladongi) & $138.44 \mathrm{~b}$ & $33.18 \mathrm{~b}$ & $1.36 \mathrm{a}$ & 49.90 \\
\hline K6 (M04) & $163.89 \mathrm{a}$ & $38.85 \mathrm{a}$ & $1.64 \mathrm{a}$ & 50.76 \\
\hline K7 (Amirudin) & $110.54 \mathrm{c}$ & $30.75 \mathrm{c}$ & $0.96 \mathrm{~b}$ & 51.52 \\
\hline K8 (Sulawesi 2) & $110.81 \mathrm{c}$ & $30.50 \mathrm{c}$ & $0.52 \mathrm{~b}$ & 52.16 \\
\hline K9 (Lambadia 01) & $132.38 \mathrm{~b}$ & $38.36 \mathrm{a}$ & $1.08 \mathrm{~b}$ & 49.29 \\
\hline K10 (BAL 209) & $106.63 \mathrm{c}$ & $26.71 \mathrm{~d}$ & $1.02 \mathrm{~b}$ & 49.02 \\
\hline K11 (KKM 22) & $132.06 \mathrm{~b}$ & $34.20 \mathrm{~b}$ & $1.14 \mathrm{~b}$ & 32.90 \\
\hline K12 (MT) & $169.90 \mathrm{a}$ & $40.66 \mathrm{a}$ & $1.55 \mathrm{a}$ & 53.36 \\
\hline Average & 126.36 & 31.94 & 1.13 & 49.58 \\
\hline Standard deviation & 23.01 & 5.57 & 0.31 & 5.41 \\
\hline
\end{tabular}

Note: The numbers followed by the same letter in each column are not significantly different according to the Scott-Knott test at the 5\% significance level

Based on the results of tests for bean quality, K12 (MT), K5 (PT. Ladongi), K1 (Sulawesi 1), and K2 (M01) were still classified in the same group, with the exception of K6 (M04), that produced a bean with the average weight $>1$ g. Several clones, such as K6 (M04), K12 (MT), K5 (PT. Ladongi), K1 (Sulawesi 1), and K2 (M01), produced a bean with an average weight of $>1 \mathrm{~g}$ (Table 4). These clones have the yield, physical attributes, and the potential to meet the selection criteria for obtaining new highyielding clone material. However, these potential advantages require further study and examination of other characteristics. The analysis showed a potential fat content of $>53.36 \%$ in the MT clone developed from local cocoa exploration, while KKM 22 had the second-highest fat content of $53.29 \%$. In addition to having the highest fat content in beans, the MT cocoa clone also produced a fairly high bean dry weight of $1.55 \mathrm{~g}$. KKM 22 also produced a high bean dry weight of $1.14 \mathrm{~g}$.

The national high-yielding clones used as the controls were Sulawesi 1, ICCRI 3, and ICCRI 4 clones, which had a fat content of $50.92 \%, 50.70 \%$, and $51.75 \%$, respectively. Therefore, the KKM 22 and MT clones have the capacity to become new high-yielding clones. These clones provide essential genetic material for cocoa breeding, and can be used as parent clones for high-fat traits and good bean quality in cross-breeding programs to produce new clones. The results of the analysis of the quality components of each clone were generally highly diverse, and not all clones had good quality or resistance components. There were three major groups based on the quality component (Figure 1).

\section{Resistance to cocoa pod borer}

\section{Percentage of sticky beans and CPB attack}

Based on the percentage of sticky beans, the observed clones were classified into three groups. The highest percentage of sticky beans $(60.6 \%)$ was observed in $\mathrm{K} 2$ (M01) from group A. The imago population in the cocoa pods of K2 was also larger; therefore, the attack level was determined as heavy for this clone. In contrast, Sulawesi 2, in group $\mathrm{C}$ with $\mathrm{K} 5$ (PT. Ladongi), had the smallest percentage of sticky beans $(16.1 \%)$. The attack level for these two clones was in the light category. The clones in group B had a moderate level of attack, with the percentage of sticky beans between $22.8 \%$ and $33.3 \%$ (Table 5 ).

The number of CPB larvae exit holes was variable across the 12 clones (Table 5). M01 and MT clones had the largest number of exit holes (6 exit holes), while PT. Ladongi, Amirudin, and Sulawesi 2 had the smallest number. Therefore, the number of exit holes appeared to be influenced by clone.

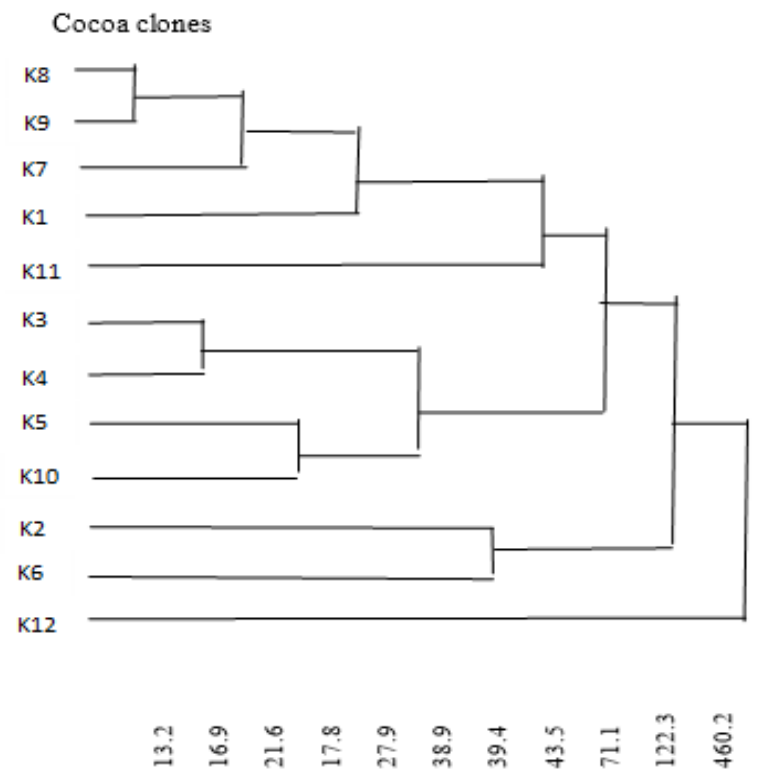

Figure 1. Cluster analysis results for 12 cocoa clones based on quality components 
Table 5. Measures indicating the level of cocoa pod borer (CPB) attack on the 12 clones in the study site

\begin{tabular}{|c|c|c|c|c|}
\hline Clones & Sticky beans (\%) & Attack level & $\begin{array}{c}\text { Average CPB- } \\
\text { attacked beans (\%) }\end{array}$ & Attack level \\
\hline K12 (MT) & $38.23 \mathrm{~b}$ & Moderate & $38.00 \mathrm{~b}$ & Moderate \\
\hline K2 (M01) & $60.60 \mathrm{a}$ & Heavy & $61.30 \mathrm{a}$ & Heavy \\
\hline K1 (Sulawesi 1) & $32.35 \mathrm{~b}$ & Moderate & $31.71 \mathrm{~b}$ & Moderate \\
\hline K6 (M04) & $30.76 \mathrm{~b}$ & Moderate & $25.30 \mathrm{~b}$ & Moderate \\
\hline K9 (Lambadia 01) & $33.33 \mathrm{~b}$ & Moderate & $33.00 \mathrm{~b}$ & Moderate \\
\hline K10 (BAL 209) & $28.12 \mathrm{~b}$ & Moderate & $25.00 \mathrm{~b}$ & Moderate \\
\hline K11 (KKM 22) & $27.27 \mathrm{~b}$ & Moderate & $28.33 \mathrm{~b}$ & Moderate \\
\hline K3 (ICCRI 03) & $22.85 \mathrm{~b}$ & Moderate & $19.00 \mathrm{~b}$ & Moderate \\
\hline K4 (ICCRI 04) & $25.00 \mathrm{~b}$ & Moderate & $19.70 \mathrm{~b}$ & Moderate \\
\hline K7 (Amirudin) & $23.68 \mathrm{~b}$ & Moderate & $22.71 \mathrm{~b}$ & Moderate \\
\hline K8 (Sulawesi 2) & $16.13 \mathrm{c}$ & Light & $16.00 \mathrm{~b}$ & Moderate \\
\hline K5 (PT. Ladongi) & $17.64 \mathrm{c}$ & Light & $18.30 \mathrm{~b}$ & Moderate \\
\hline Average & 29.66 & & 28.20 & \\
\hline Standard deviation & 11.65 & & 12.36 & \\
\hline
\end{tabular}

Note: The numbers followed by the same letter in each column are not significantly different according to the Scott-Knott test at the 5\% significance level

The 12 clones used in this study can be classified into two groups based on the CPB larval attack rate. K2 (M01) had the highest percentage of damaged beans $(61.3 \%)$, and its attack level was categorized as heavy, whereas the damage to beans in other clones was only 16-38\% and was, therefore, the level of attack was moderate. However, the evaluation of quality characteristics and resistance to this disease is a pilot process to obtain resistant cocoa clones; therefore, further efforts and research are still required to identify more efficient and effective clones for cocoa production based on selection criteria for resistance.

The analysis of quality and characteristics of the cocoa pods showed differences in trichome density. The number of tannin granules distributed in the mesocarp layer and the sclerotic layer of the cocoa pods differed between clones and showed differences in response to CPB attack. It can be used as a criterion for selecting for CPB resistance (Susilo et al. 2007). Damage to cocoa beans due to CPB attack is 2-3 months before harvest or during the infestation process of CPB eggs on the fruit. Susilo et al. (2009) stated that the fluctuations in the imago population did not affect the level of plant resistance because the percentage of sticky beans was higher. In this case, the dynamics of the CPB population in the field affected CPB attack of fruit. This phenomenon can be influenced by biotic and abiotic factors in the research environment; therefore, the assumption was that it was not influenced by genetic differences in CPB.

\section{Number of entry and exit holes of CPB larvae}

The variance analysis showed a significant difference between clones in the number of entry holes of CPB larvae. Based on the results, the 12 clones could be categorized into two different groups. $\mathrm{K} 3, \mathrm{~K} 4, \mathrm{~K} 5, \mathrm{~K} 6, \mathrm{~K} 7, \mathrm{~K} 8, \mathrm{~K} 9$, $\mathrm{K} 10$, and $\mathrm{K} 11$ were grouped together as having similar numbers of CPB larvae entry holes. Based on the number of CPB larvae exit holes, the clones could also be differentiated into two groups. K12 (MT), K2 (M01), K1 (Sulawesi 1), K6 (M04), and K9 (Lambandia 01) had similar numbers of exit holes, and were significantly different from K4 (ICCRI 04), K10 (BAL 209), K11 (KKM 22), K3 (ICCRI 03), K8 (Sulawesi 2), K7 (Amirudin), and K5 (PT. Ladongi) (Table 6). The percentage of CPB larvae exit holes in K12 (MT) illustrated the yield loss due to CPB attack, which caused a reduction in the number of healthy beans (Day 1989). Thus, this grouping is in line with pod rot disease resistance.

K12 (MT) had the highest average percentage $(6 \%)$ of CPB larvae exit holes The ratio of the number of CPB larvae exit holes to the number of entry holes differed between the clones. This variation was associated with differences in the resistance response to CPB attack (AduAcheampong et al. 2015). The CPB larvae exit holes: entry holes ratio indicates the rate of larval movement to exit from the pods. Thus, clones that have a lower ratio are expected to be able to suppress the movement of larvae out of the fruit. Frequent harvesting and breaking pods into small pieces after harvesting are possible ways to disrupt the life cycle of CPB (Lim 1992; Saripah and Alias 2016). The average percentage of larval exit holes varied considerably between clones and was 2-6\%. Nevertheless, based on this range of values, the maximum limit for the selection criteria is unknown.

There were differences in fruit characteristics between cocoa clones indicating a varied resistance response to $\mathrm{CPB}$ (Susilo et al. 2007). The clones displaying a relatively low number of larval entry holes had a moderately high density of trichome tissue and a large number of tannin granules. Based on these two characteristics, it was assumed that trichomes function in the antixenosis mechanism by inhibiting the egg-laying process, while tannin granules play a role in the antibiotic mechanism in the mesocarp layer. Differences in lignification of the sclerotic layer of fruit have also been reported to differ between moderate and susceptible clones. The CPB-resistant clones exhibited a higher rate of sclerotic layer lignification and greater primary groove thickness than moderately resistant clones and susceptible clones (Susilo 2009). 
Table 6. Average number of cocoa pod borer (CPB) larvae entry and exit holes in the study site

\begin{tabular}{lcc}
\hline \multicolumn{1}{c}{ Clones } & $\begin{array}{c}\text { Number of } \\
\text { entry holes of } \\
\text { CPB larvae }\end{array}$ & $\begin{array}{c}\text { Number of exit } \\
\text { holes of CPB } \\
\text { larvae }\end{array}$ \\
\hline K12 (MT) & $8 \mathrm{a}$ & $6 \mathrm{a}$ \\
K2 (M01) & $8 \mathrm{a}$ & $6 \mathrm{a}$ \\
K1 (Sulawesi 1) & $6 \mathrm{~b}$ & $5 \mathrm{a}$ \\
K6 (M04) & $5 \mathrm{~b}$ & $4 \mathrm{a}$ \\
K9 (Lambadia 01) & $5 \mathrm{~b}$ & $4 \mathrm{a}$ \\
K10 (BAL 209) & $5 \mathrm{~b}$ & $3 \mathrm{~b}$ \\
K11 (KKM 22) & $5 \mathrm{~b}$ & $3 \mathrm{~b}$ \\
K3 (ICCRI 03) & $4 \mathrm{~b}$ & $3 \mathrm{~b}$ \\
K4 (ICCRI 04) & $4 \mathrm{~b}$ & $4 \mathrm{~b}$ \\
K7 (Amirudin) & $3 \mathrm{~b}$ & $2 \mathrm{~b}$ \\
K8 (Sulawesi 2) & $3 \mathrm{~b}$ & $2 \mathrm{~b}$ \\
K5 (PT. Ladongi) & $3 \mathrm{~b}$ & $2 \mathrm{~b}$ \\
Average & 4.92 & 3.67 \\
Standard deviation & 1.73 & 1.44 \\
\hline
\end{tabular}

Note: The numbers followed by the same letter in each column are not significantly different according to the Scott-Knott test at the $5 \%$ significance level.

Table 7. Results for the test on resistance to cocoa pod rot (CPR) disease in the 12 clones in the study site

\begin{tabular}{llll}
\hline \multirow{2}{*}{ Clones } & \multicolumn{2}{c}{ Observed variables } & \\
\cline { 2 - 3 } & $\begin{array}{c}\text { Average } \\
\text { no. of rotten } \\
\text { fruits }\end{array}$ & $\begin{array}{c}\text { Intensity } \\
(\%)\end{array}$ & Description \\
\hline K1 (Sulawesi 1) & $12 \mathrm{~b}$ & 50 & Rather resistant \\
K2 (M01) & $12 \mathrm{~b}$ & 100 & Susceptible \\
K3 (ICCRI 03) & $18 \mathrm{a}$ & 75 & Rather resistant \\
K4 (ICCRI 04) & $18 \mathrm{a}$ & 70 & Rather resistant \\
K5 (PT. Ladongi) & $6 \mathrm{c}$ & 18 & Resistant \\
K6 (M04) & $10 \mathrm{~b}$ & 70 & Rather resistant \\
K7 (Amirudin) & $10 \mathrm{~b}$ & 100 & Susceptible \\
K8 (Sulawesi 2) & $21 \mathrm{a}$ & 60 & Moderate \\
K9 (Lambadia 01) & $12 \mathrm{~b}$ & 40 & Rather resistant \\
K10 (BAL 209) & $6 \mathrm{c}$ & 20 & Resistant \\
K11 (KKM 22) & $10 \mathrm{~b}$ & 45 & Rather resistant \\
K12 (MT) & $12 \mathrm{~b}$ & 100 & Susceptible \\
Average & 12.25 & 62.33 & \\
Standard deviation & 4.63 & 29.00 & \\
\hline
\end{tabular}

Note: The numbers followed by the same letter in the column are not significantly different according to the Scott-Knott test at the $5 \%$ significance level

Susilo (2009) reported results for the effect of fruit development on performance characteristics of these traits using the same clone types. The preference for laying egg and the number of visits varied depending on host plants. The most recently introduced host plants are likely preferred by CFB (Niogret 2020). Pests (butterfly pests) usually lay eggs on young cocoa pods aged 2-3 months. This was also found to be the case in K12 with the rate of entry holes of CPB larvae at $8 \%$ as reported by Indrayani (2008) for trichome tissue in the antixenosis mechanism for pest resistance. Cocoa clones with high-quality beans, a fat content of more than $50 \%$, and resistance to pests and diseases can be used as material for clonal propagation by local farmers while awaiting the release of new highyielding clones.

\section{Resistance to cocoa pod rot disease}

Based on the results of further Scott-Knott tests for CPR resistance, three different groups could be identified among the 12 clones. K8, K3, and $\mathrm{K} 4$ produced the highest number of rotten fruit compared to the other clones. K9, $\mathrm{K} 12$, K1, K2, K11, K7, and K6 produced a substantial number of rotten fruits while $\mathrm{K} 10$ and $\mathrm{K} 5$ had the smallest number of rotten fruit compared to the other clones (Table 7).

This result was slightly different from that of McMahon et al. (2015) who found both M01 and ICCRI 04 to be susceptible clones with a higher incidence of disease. Dewi et al. (2020) found five very resistant clones of Sulawesi while Chang et al. (2020) categorized 50 cocoa genotypes in Malaysia into four groups based on the tolerance level. $P$. palmivora is a pathogen of many plant species in tropical and temperate regions. In cocoa, it attacks leaves, stems, shoots, flowers, and fruit at various ages. However, young fruit is the most sensitive and susceptible to pathogen attack and infection (Akrofi et al. 2015; Ling et al. 2017) because young pods are thought to contain less carbohydrate (Ling et al. 2017). The most intense damage from infection occurs during the two months before the fruits are ripe. Fruit infection at this stage can cause total loss because pathogens can easily enter the ovule layer of the developing green fruit through the skin of the fruit (http://www.oardc.ohw-state-edu/cocoa/blackpod.htm).

Phytophthora infection may increase in soils with high levels of moisture (Akrofi et al. 2015). According to Ali et al. (2017), increasing frequency and pore size will increase the level of cocoa plant susceptibility.

Cocoa plant spacing adjustment (Acebo-Guerrero et al. 2012), garden and crop sanitation such as weed control, pruning (Armengot et al. 2020), frequent harvests (Adeniyi 2019; Armengot et al. 2020), use of microorganisms (bacteria) such as Pseudomonas putida (Akrofi et al. 2017), $P$. aeruginosa and Chryseobacterium proteolyticum (Alsultan et al. 2019) as biological control agents, use of fungicides (Acebo-Guerrero et al. 2012; Ndoungue et al. 2018), spraying interval management (Martjin ten Hoopen et al. 2012), trunk injection using phosphonate (McMahon et al. 2010b), and frequent removal of diseased pods (Armengot et al. 2020) are some of the crucial measures for controlling the disease. Covering cocoa pods with degradable plastic sleeves was found to control Phytophthora pod rot (Rosmana et al. 2010). Farmers' knowledge of cocoa pod growth will be beneficial to implement disease management (Martjin ten Hoopen et al. 2012).

The efforts to control diseases involve not only paying attention to the pathogen, but also considering the environment and host plants. Among the most influential environmental factors in disease control are rainfall, humidity, and temperature. They can be manipulated through cultivation practices (culture techniques) to inhibit the rate of disease progression. Suppression of the initial 
state of the disease can also be achieved by using resistant clones, together with sanitation and canopy management.

CPR disease is very difficult to control because pathogens can generally survive as mycelium and chlamydospores (resistant spores with thick walls) in infected plant material, such as roots, stems, flowers, leaves (Acebo-Guerrero 2012; Ali et al. 2017), and fruit (Edy et al. 2019), or in the soil (Acebo-Guerrero 2012; Adeniyi 2019). P. palmivora is found in various cocoa centers in Indonesia, and resistance to CPR disease is mostly influenced by the action of additive genes on the proportion of dominant genes relative to recessive genes in parents.

\section{ACKNOWLEDGEMENTS}

We are grateful to the ACIAR Cocoa Project, Indonesian Industry and Freshener Crops Research Institute (IFCRI), and Assessment Institute for Agricultural Technology (AIAT) of Southeast Sulawesi for financing our research. We would like to thank the technicians at the Indonesian IFCRI and AIAT of South East Sulawesi for assistance during research and data collection.

\section{REFERENCES}

Acebo-Guerrero Y, Hernández-Rodríguez A, Heydrich-Pérez M, Jaziri ME, Hernández-Lauzardo AN. 2012. Management of black pod rot in cacao (Theobroma cacao L.): a review. Fruits 6 (1): 41-48.

Abdulai I, Hoffman MP, Jassogne L, Asare R, Graefe S, Hsiao-Hang T, Muilerman S, Vaast P, Van Asten P, Läderach P, Rötter RP. 2020. Variations in yield gaps of smallholder cocoa systems and the main determining factors along a climate gradient in Ghana. Agric Syst 181 (2020): 1-8.

Adeniyi D. 2019. Diversity of cacao pathogens and impact on yield and global production. In: Aikpokpodian P (eds.). Theobroma cacaoDeploying Science for Sustainability of Global Cocoa Economy. IntechOpen, London.

Adu-Acheampong R, Sarfo JE, Appiah EF, Nkansah A, Awudzi G, Obeng E, Tagbor P, Sem R. 2015. Strategy for insect pest control in cocoa Amer J Exp Agric 6 (6): 416-423.

Afoakwa EO, Quao J, Takrama J, Budu AS, Saalia FK. 2011a. Effect of pulp preconditioning on acidification, proteolysis, sugars and free fatty acids concentration during fermentation of cocoa (Theobroma cacao) beans. Intl J Food Sci Nutr 62 (7): 755-764.

Afoakwa EO, Quao J, Takrama J, Budu AS, Saalia FK. 2011b. Chemical composition and physical quality characteristics of Ghanaian cocoa beans as affected by pulp pre-conditioning and fermentation. J Food Sci Technol. DOI: 10.1007/s13197-011-0446-5.

Afoakwa EO, Kongor JE, Budu AS, Mensah-Brown H, Takrama JF 2014. Changes in some biochemical qualities during drying of pulp pre-conditioned and fermented cocoa (Theobroma cacao) beans. Afr J Food Agric Nutr Dev 15 (1): 9651-9670.

Akrofi AY, Amoaka-Atta I, Assua M, Asare EK. 2015. Black pod disease on cacao (Theobroma cacao, L) in Ghana: Spread of Phytophthora megakarya and role of economic plants in the disease epidemiology. Crop Protection 72: 66-75.

Akrofi AY, Terlabie JL, Amoaka-Atta I, Asare EK. 2017. Isolation and characterization of bacteria from different cacao progenies and their antagonistic activity against the black pod disease pathogen, Phytophthora palmivora. J Plant Dis Prot 124: 143-152.

Ali SS, Shao J, Lary DJ, Strem MD, Meinhardt LW, Bailey BA. 2017 Phytophthora megakarya and P. palmivora, causal agents of black pod rot, induce similar plant defense responses late during infection of susceptible cacao pods. Front Plant Sci 8: 169. DOI: 10.3389/fpls.2017.00169.

Alsultan W, Vadamalai G, Khairulmazmi A, Saud HM, Al-Sadi AM, Rashed O, Jaaffar AKM, Nasehi A. 2019. Isolation, identification and characterization of endophytic bacteria antagonistic to Phytophthora palmivora causing black pod of cocoa in Malaysia. Eur J Plant Pathol. DOI: 10.1007/s10658-019-01834-8.

Apriyanto M. 2016. Changes in chemical properties of dried cocoa (Theobroma cacao) beans during fermentation. Intl J Food Ferment 5 (1): 11-16.

Apriyanto M, Sutardi, Supriyanto, Harmayani E. 2016. Study on effect of fermentation to the quality parameter of cocoa bean in Indonesia. Asian J Dairy Food Res 35 (2): 160-163.

Armengot L, Ferrari L, Milz J, Velásquez F, Hohmann P, Schneider M. 2020. Cacao agroforestry systems do not increase pest and disease incidence compared with monocultures under good cultural management practices. Crop Protect 130: 1-9. DOI: 10.1016/j.cropro.2019.105047.

Azhar I, Long GE, Musa MJ. 1995. Qualitative and multivariate analyses of clonal resistance to cocoa pod borer. Planter 71: 307-321.

Campos-Vega R, Nieto-Figuero KH, Oomah BD. 2018. Cocoa (Theobroma cacao L.) pod husk: Renewable source of bioactive compounds. Trends Food Sci Technol 81: 172-184.

Chang ALS, Salleh S, Yazik NM, Ramba H, Jaaffar AKM. 2020. Grouping tolerant level of cocoa genotypes against pod rot disease in Malaysia. Pelita Perkebunan 36 (2): 139-153.

Day, RK. 1989. Effect of cocoa pod borer conophomorpha cramerella, on cocoa yield and quality in Sabah, Malaysia. Crop Protection 83328339.

Daymond AJ, Acheampong K, Prawoto A, Abdoellah A, Addo G, AduYeboah P, Arthur A, Cryer NC, Dankwa YN, Lahive F, Konlan S, Susilo A, Turnbull CJ, Hadley P. 2017. Mapping cocoa productivity in Ghana, Indonesia and Côte d'Ivoire. International Symposium on Cocoa Research (ISCR), Lima, Peru, 13-17 November 2017.

Deepa R, Balakrishnan S, Jegadeeswari V, Thiribhuvanamala G, N Kumaravadivel N. 2019. Evaluation of cocoa half-sib selection for morphological and yield traits under Tamil Nadu conditions. J Pharmacogn Phytochem 8 (3): 768-770.

Dewi VS, Asman A, Josua K, Hamdayanty H. 2020. Resistance test of five cocoa (Theobromae cacao L.) clones in South Sulawesi against Phytophthora palmivora. IOP Conf Ser Earth Environ Sci 486 (2020): 012173. DOI: 10.1088/1755-1315/486/1/012173.

Directorate General of Estate Crops. 2019. Tree crops estate statistics of Indonesia 2017-2019: cocoa. Directorate General of Estate Crops. The Ministry of Agriculture, Jakarta. www.ditjenbun.pertanian.go.id. [Indonesian].

Edy N, Angelia M, Lakani I, Panggeso J. 2019. Current status on cacao disease incidence in Central Sulawesi. Agroland Agric Sci J 6 (1): 57 62.

Effendy, Pratama MF, Rauf RA, Antara M, Cyio MB, Mahfudz, Muhardi. 2019. Factors influencing the efficiency of cocoa farms: A study to increase income in rural Indonesia. PLoS ONE 14(4): e0214569. DOI: 10.1371 journal.pone.0214569.

Efombagn, MIB, Bieysse D, Nyasśe S, Eskes AB. 2011. Selection for resistance to Phytophthora pod rot of cocoa (Theobroma cacao L.) in Cameroon: Repeatability and reliability of screening tests and field observations. Crop Protection 30: 105-110.

Fry WE. 1982. Principles of Disease Management. Academic Press, New York.

Giacometti J, Jolić SM, Josić D. 2015. Cocoa processing and impact on composition. In: Preedy VR (eds.). Processing and Impact on Active Components in Food Edition: First Edition 2015. Chapter: 73. Section 8 Beverages. Academic Press, London.

Glorya MJ, Nugraha A. 2019. Private sector initiatives to boost productivity of cocoa, coffee, and rubber in Indonesia. Discussion Paper No. 8. Center for Indonesian Policy Studies, Jakarta.

Gu F, Tan L, Wu H, Fang Y, Xu F, Chu Z, Wang Q. 2013. Comparison of cocoa beans from China, Indonesia and Papua New Guinea. Foods 2: 183-197.

Hashimoto JC, Lima JC, Celeghini RMS, Nogueira AB, Efraim P, Poppi RJ, Pallone JAL. 2018. Quality control of commercial cocoa beans (Theobroma cacao L.) by near-infrared spectroscopy. Food Analytical Methods. DOI: 10.1007/s12161-017-1137-2.

Hastuti S, Bintoro N, Karyadi NW, Pranoto Y. 2019. Characteristics of dried cocoa beans (Theobroma cacao L.) color using response surface methodology. Plant Tropika: Jurnal Agrosains (J Agric Sci) 7 (1): 82 92.

ICCO. 2019. Production of cocoa beans. Quart Bull Cocoa Stat 45: 3. https://www.icco.org/about-us/icco-news/408-may-2019-quarterlybulletin-of-cocoa-statistics.html 
Indonesian National Standard. 2002. Cocoa beans (SNI 01-2323-2002). National Standardization Center, Jakarta. [Indonesian].

Indrayani IGAA. 2008. The role of plant morphology to control leaf sucker of Amrasca biguttula (Ishida) in cotton plants. Perspective 7 (1): 47-54.

Kongor JE, Hinneh M, de Walle DV, Afoakwa EO, Boeckx P, Dewettinck K. 2016. Factors influencing quality variation in cocoa (Theobroma cacao) bean flavour profile - A review. Food Res Intl 82: 44-52.

Lefeber T, Janssens M, Moens F, Gobert W, Vuyst LD. 2011. Interesting starter culture strains for controlled cocoa bean fermentation revealed by simulated cocoa pulp fermentations of cocoa-specific lactic acid bacteria. Appl Environ Microbiol 77: 6694-6698.

Lim GT. 1992. Biology, ecology and control of cocoa pod borer Conopomorpha cramerella (Snellen). In: Keane PJ, Putter CAJ (eds.). Cocoa Pest and Diseases Management in Southeast Asia and Australia. FAO, Rome.

Ling ASC, Kamil MJA, Chong KP, Ho CM. 2017. Assessing the cocoa genotypes for resistance to black pod using the area under the diseaseprogress curve (AUDPC). Bulgarian J Agric Sci 23 (6): 972-979.

Martjin ten Hoopen G, Deberdt P, Mbenoun M, Cilas C. 2012. Modelling cacao pod growth: implications for disease control. Ann Appl Biol 160: 260-272.

McMahon PJ, Purwantara A, Susilo AW, Sukamto S, Wahab A, Purung HB, Hidayat M, Ismail D, Taproni T, Lambert S, Guest D, Keane P. 2010a. On-farm selection for quality and resistance to pest/diseases of cocoa in Sulawesi: (ii) quality and performance of selections against Phytophthora pod rot and vascular-streak dieback. Intl J Pest Manag 56 (4): 351-361.

McMahon PJ, Purwantara A, Wahab A, Imron M, Lambert S, Keane PJ, Guest DI. 2010b. Phosphonate applied by trunk injection controls stem canker and decreases Phytophthora pod rot (black pod) incidence in cocoa in Sulawesi. Australasian Plant Pathol 39: 170175.

McMahon PJ, Purung HB, Lambert S, Mulia S, Nurlaila, Susilo AW, Sulistyowati E, Sukamto S, Israel M, Saftar A, Amir A, Purwantara A, Iswanto A, Guest D, Keane P. 2015. Testing local cocoa selections in three provinces in Sulawesi: (i) Productivity and resistance to cocoa pod borer and Phytophthora pod rot (black pod). Crop Protect 70 (2015): 28-39.

Ndoungue M, Petchayo S, Techou Z, Nana WG, Nembot C, Fontem D, Ten Hoopen GM. 2018. The impact of soil treatments on black pod rot (caused by Phytophthora megakarya) of cacao in Cameroon. Biol Control 2018: 1-34.

Ndoungue M, Petchayo S, Techou Z, Nana WG, Nembot C, Fontem D, Ten Hoopen GM. 2018. The impact of soil treatments on black pod rot (caused by Phytophthora megakarya) of cacao in Cameroon. Biological Control 2018: 1-34.

Niogret J, Ekayanti A, Kendra PE, Ingram K, Lambert S, Epsky ND Marelli JP. 2020. Host preferences of the cocoa pod borer, Conopomorpha cramerella, the main threat to cocoa production in Southeast Asia. Entomologia Experimentalis et Applicata 168: 221227.

Oddoye EOK, Agyente-Badu C, Gyedu-Akoto E. 2013. Cocoa and its byproducts: identification and utilization. In: Watson R, Preedy V, Zibadi S (eds.). Chocolate in Health and Nutrition. Nutrition and Health, Vol 7. Humana Press, Totowa, NJ. DOI: 10.1007/978-161779-803-0_3.

Owosu M. 2010. Influence of raw material and processing on aroma in chocolate. [Dissertation]. Faculty of Life Science, University of Copenhagen, Denmark
Quelal-Vásconez MA, Lerma-García MJ, Pérez-Esteve E, Talens P, Barat JM. 2020. Roadmap of cocoa quality and authenticity control in the industry: A review of conventional and alternative methods. Compr Rev Food Sci and Food Saf 19: 448-478.

Rojas KE, García MC, Cerón IX, Ortiz RE, Tarazona MP. 2020. Identification of potential maturity indicators for harvesting cacao.Heliyon 6: e03416. DOI: 10.1016/j.heliyon.2020.e03416.

Rosmana A, Shepard M, Hebbar P, Mustari A. 2010. Control of cocoa pod borer and Phytophthora pod rot using degradable plastic pod sleeves and a nematode, Steinernema carpocapsae. Indon J Agric Sci 11 (2): 41-47.

Rubiyo, Siswanto. 2012. Increased production and development of cocoa (Theobroma cacao L) in Indonesia. Buletin Riset Tanaman Rempah dan Aneka Tanaman Industri 3 (1): 33-48. [Indonesian].

Rubiyo, Dewi YA. 2018. The status of the arabica coffee commodity (Coffee arabica L) and its development area in Indonesia. In: Pasandaran E, Syakir M, Yufdy MP (eds.) Innovation Synergy Strengthens Smallholder Agriculture Based on Plantation Crops and Spices. IAARD Press, Jakarta. [Indonesian].

Ruf F, Yaddang. 2014. Indonesia cocoa sector assessment how to help Indonesian cocoa farmers to re-invest in cocoa? Synthesis for The World Bank. CIRAD, UMR Innovation, Montpellier, France.

Saripah B, Alias A. 2016. Evaluation of best management practices for cocoa pod borer in cocoa ecosystem. Malaysian Cocoa J 9 (1): 108120.

Sudibyo A. 2017. Effect of processing techniques on flavour and characteristics of cocoa processed and chocolate products. Jurnal Industri Hasil Perkebunan. 12 (1): 1-13. [Indonesian]

Sulistyowati E, Wardani W, Mufrihati E. 2005. Development of monitoring techniques for Conopomorpha cramerella snell cocoa pod borer (CPB). Pelita Perkebunan 21 (3): 159-168. [Indonesian].

Sulistyowati E, Santosa AB. 1992. Introduction of the main pests of the cocoa plant and how to control. Bahan Pengolahan Kakao. Puslitkoka, 26 Oct-7 Nov 1992. [Indonesian].

Sulistyowaty, Sulisyowati E. 1993. The effect of cocoa pod borer (CPB) attack on the quality of cocoa beans. Warta Pusat Penelitian Kopi dan Kakao 15: 29-35. [Indonesian].

Susilo AW, Sulistiyowati E, Mufrihati E, Wahab A, McMahon P, Purwantara A, Iswanto. 2006. Selection for Improved quality and resistance of phytophthora pod rot, cocoa pod borer, and vascular streak dieback on cocoa in Indonesia. Annual Progress Report. ACIAR, Australia.

Susilo, AW, Mangoendidjojo W, Witjaksono. 2007. The relationship between the characteristics of the fruit skin tissue of several cocoa clones (Theobroma cacao L.) and the resistance of cocoa pod borer. Pelita Perkebunan 23: 159-175. [Indonesian].

Susilo AW, Mangoendidjojo W, Witjaksono, Mawardi S. 2009. Influence of fruit age development of several cocoa clones against the demonstration of cocoa fruit borer pest resistance. Pelita Perkebunan 25: 1-11. [Indonesian].

Teye E, Anyidoho E, Agbemafle R, Sam-Amoah LK, Elliott C. 2019. Cocoa bean and cocoa bean products quality evaluation by NIR spectroscopy and chemometrics: a review. Infrared Physics \& Technol. DOI: 10.1016/j.infrared.2019.103127.

Tothmihaly A, Verina I. 2017. How can the productivity of Indonesian cocoa farms be increased? Global Food Discussion Papers No. 103. July 2017: 1-30.

Witjaksono J, Asmin. 2016. Cocoa farming system in Indonesia and its sustainability under climate change. Agric For Fish 5 (5): 170-180. 